\title{
Passive House Alternative Proposal for the Brazilian Bioclimatic Zone 8
}

\author{
Alexandre S. Cruz ${ }^{*}$, Ramon S. de Carvalho², Eduardo G. da Cunha ${ }^{3}$ \\ ${ }^{1}$ Departament of Architecture and Urbanism, Pontifical Catholic University of Rio de Janeiro, Rio de Janeiro 22451-900, \\ Brazil \\ ${ }^{2}$ Departament of Architecture and Urbanism, Federal University of Santa Catarina, Florianópolis 88040-900, Brazil \\ ${ }^{3}$ Faculty of Architecture and Urbanism, Federal University of Pelotas, Pelotas 96010-610, Brazil
}

Corresponding Author Email: scruzalexandre@gmail.com

https://doi.org/10.18280/ijsdp.150605

Received: 24 June 2020

Accepted: 17 August 2020

\section{Keywords:}

passive house, energy efficiency,

sustainability

\begin{abstract}
The energy consumption in buildings accounts for a significant portion of energy production worldwide hence there is a growing interest in the development of more efficient projects. One way to achieve buildings with low energy consumption while maintaining a high thermal comfort is the Passive House concept. This paper discusses the alternative approach of the Passive House standard for hot climates. The certification refers to a low-energy building standard for cold climate regions that the indoor comfort conditions can be maintained yearround with a specific minimum energy consumption target. There cannot be a single Passive House concept since there are climatic variations. Thus, the Passive House Institute reviewed the proposal for the application of the standard to meet hot climate regions around the world. This study is located in Rio de Janeiro, Brazil and considered a residential project proposal for the city of Pelotas, Brazil. The EnergyPlus software performed the new simulations, to verify the potential of the Passive House concept adoption in Brazil, whose territory is mainly characterized by hot climates.
\end{abstract}

\section{INTRODUCTION}

Based on the Brazilian National Energy Balance, 2019 (BEN), there is a growing demand for energy since 2015, mainly due to economic development and population growth. Buildings are responsible for $50 \%$ of the consumption of electricity and the residential sector is the largest consumer, accounting for $25 \%$ of this demand [1].

The energy consumption of cooling systems in residential buildings is expected to increase because when living standards rise, the need for comfort also increases. It is believed that the conditioned spaces will grow by $80 \%$ in emerging economies, increasing energy demand in cities, where the greatest potential for energy savings lies [2]. Thus, the new homes represent an opportunity to implement innovative policy and technology solutions that can limit energy demand for buildings.

Meantime, in Brazil the discussions on thermal performance and energy efficiency are recent. The crisis in the energy sector that occurred in 2001 forced the country to pursue more efficient measures to rationalize the consumption of electricity [3]. The first Brazilian standards for the assessment of thermal performance established were: NBR 15220 in 2005 and NBR 15575 in 2008 . The first evaluates the thermal performance of social housing. It presents calculations methods of thermal transmittance ( $U$-value), thermal capacity, thermal delay and solar factor of the building components, constructive guidelines and bioclimatic strategies [4]. The second evaluates the performance of residential buildings and set 13 aspects to be considered during the analysis, including thermal performance [5]. Finally, in 2010, the Brazilian National
Institute of Meteorology, Quality, and Technology (INMETRO) published the Technical Quality Regulation for the Energy Efficiency Level for Residential Buildings (RTQ$\mathrm{R})$. The regulation specifies the technical requirements and methods for classification of buildings for energy efficiency on a scale ranging from " $\mathrm{A}$ " to " $\mathrm{E}$ ", from the highest efficiency to the lowest efficiency, respectively [6].

One possible way to achieve more energy efficient buildings is the implementation of the Passive House standard [7]. In the city of Pelotas - Brazil, it was developed a project to be constructed at the Federal University of Pelotas that aims to meet all requirements of Passive House standard. This experience aimed to understand all the premises of the adapted standard for southern European countries (Passive-On) and its applicability in Brazil [8, 9].

The objective of this paper is to evaluate the potential of the Passive House standard in Brazil, especially in the Brazilian Bioclimatic Zone 8 (ZB8), in which the territory is characterized by the tropical climate. The study is based on computational simulation using EnergyPlus software. The hypothetical study comprises the residential project proposal in the city of Pelotas - Brazil but is considered to be located in the city of Rio de Janeiro - Brazil.

\section{MATERIAL AND METHODS}

The study was conducted in three main stages: literature review, computer simulation, and analysis of results. First, it was carried out a literature review to understand the concepts of Passive House standard. In the second stage, it was 
evaluated thought computer simulation the performance of the case study in the city of Rio de Janeiro. The assessment compares the energy predicted results of the Passive House concept and the Brazilian standard NBR 15575 traditional guidelines. The thermal transmittance and absorptance of the envelope (external walls and roof) are the variable parameters for this study. Finally, in the third stage, the results of the research were analyzed.

\subsection{Literature review}

The Passive House is the result of the passive design method proposed by Wolfgang Feist and Bo Adamson in a residence at Darmstadt, Germany [7]. The Passive House was a success in central Europe (Austria, Belgium, Switzerland and Sweden), but the southern European countries (Spain, Italy, Portugal, and Greece) demanded an adapted version of the standard (alternative) based on the climatic variation [8, 9]. The standard is designed and built using the five design principles: high thermal insulation of the envelope, efficient windows, mechanical ventilation with heat recovery (MVHR), airtightness and reduction of thermal bridges [10]. Table 1 provides the Passive House design strategies requirements for each design principles mentioned.

Table 1. Passive House design strategies

\begin{tabular}{ccc}
\hline Passive House Principle & Parameters & Alternative \\
\hline MVHR & Minimum airflow of $30 \mathrm{~m}^{3} / \mathrm{h}$ per person \\
Airtightness & Less than 0.6 air changes per hour at a pressure difference of $50 \mathrm{~Pa}$ \\
Windows & $U$-value below $1.0 \mathrm{~W} / \mathrm{m}^{2} \mathrm{~K}$ with solar factor greater than 0.5 \\
Thermal Bridges & \multicolumn{2}{c}{$\mathrm{psi}(\Psi)$ lower than $0.01 \mathrm{~W} /(\mathrm{mK})}$. \\
Envelope Thermal insulation & $U$-value below $0.15 \mathrm{~W} / \mathrm{m}^{2} \mathrm{~K}$ & $U$-value above $0.30 \mathrm{~W} / \mathrm{m}^{2} \mathrm{~K}$ \\
\hline Note: $U$-value $=$ thermal transmittance; Source: $[7,8]$ &
\end{tabular}

The ventilation of a Passive House must be done through a mechanical ventilation with heat recovery (MVHR). The principle of this system is to reuse the heat contained in the exhaust air and transfer it to the air that is introduced into the building, through a heat exchanger, to reduce the need for heating [7]. The system should be sized to ensure a minimum airflow of $30 \mathrm{~m}^{3} / \mathrm{h}$ of air per person in residential buildings, ensuring hygienic comfort. The same process can be used for refrigeration [11].

In Passive House buildings, the building envelope must be airtight, avoiding the crack of unwanted air into the indoor environment. It must be proven by a blower door test result of less than 0.6 $\mathrm{ACH}$ (air changes per hour) at a pressure difference of $50 \mathrm{~Pa}$ [8]. Infiltrations can significantly increase the heating and cooling energy demand in buildings, causing discomfort and humidity inside the building, reducing its performance and useful life [7]. Therefore, membranes of different materials, such as wood or aluminium foil, must be used to avoid infiltrations [12].

The Passive House Institute (PHI) established that the thermal transmittance ( $U$-value) of windows cannot exceed $1.0 \mathrm{~W} / \mathrm{m}^{2} \mathrm{~K}$. Additionally, it is recommended that the windows have a high solar factor, greater than 0.5 , enabling the use of solar radiation in the winter period [8].

The certification recommends that all thermal bridges must have a value psi $(\Psi)$ lower than $0.01 \mathrm{~W} /(\mathrm{m} . \mathrm{K})$. Thermal bridges are areas of the building envelope that have lower thermal resistance compared to adjacent areas. In these areas, the heat flow is greater when there is a temperature difference between the indoor and outdoor environments [13]. This phenomenon should be avoided using thermal insulation, preventing additional linear and punctual energy loss.

The high thermal insulation of the envelope avoids heat exchanges between the interior and exterior of the building, consequently, avoiding excessive energy consumption for the heating and cooling [13]. In the Passive House standard, all elements of the opaque envelope must have low thermal transmittance value, the recommended $U$-value is below 0.15 $\mathrm{W} / \mathrm{m}^{2} \mathrm{~K}[8]$. According to the adapted version of the standard (Passive-On), depending on the weather conditions, the thermal transmittance can be above $0.30 \mathrm{~W} / \mathrm{m}^{2} \mathrm{~K}$ [7].
Afterward combining these five design strategies, the project must meet a specific minimum energy consumption required to be certified. The document with the criteria for the certification offers three different classifications: Classic, Plus, and Premium, depending on the demand for Primary Renewable Energies (PER) and the renewable energy generated [7]. Table 2 provides the Energy Demand Method that must be pursued.

Table 2. Energy demand method

\begin{tabular}{ccccc}
\hline $\begin{array}{c}\text { Passive House } \\
\text { Standard }\end{array}$ & \multicolumn{3}{c}{ Parameters } & Alternative \\
\hline $\begin{array}{c}\text { Demand for Primary } \\
\text { Energy Renewable } \\
(\text { PER) }\end{array}$ & Classic & Plus & Premium & \\
{$\left[\mathrm{kWh} /\left(\mathrm{m}^{2} \mathrm{y}\right)\right]$} & 60 & 45 & 30 & \pm 15 \\
$\begin{array}{c}\text { Renewable energy } \\
\text { generation }\end{array}$ & Classic & Plus & Premium & \\
{$\left[\mathrm{kWh} /\left(\mathrm{m}^{2} \mathrm{y}\right)\right]$} & $\mathrm{x}$ & 60 & 120 & \pm 15 \\
\hline Source: $[7,8]$ & & & &
\end{tabular}

The Pelotas Passive House proposal was considered in this study. The architectural design of the building was developed based on passive strategies used in the design of the bioclimatic house of Pouey [14] and following the compliance criteria required by the Passive House Standard [15, 16]. The Figure 1 presents the residential project that was modeled using the SketchUp software and through Legacy Open Studio plugin simulated in EnergyPlus Software.

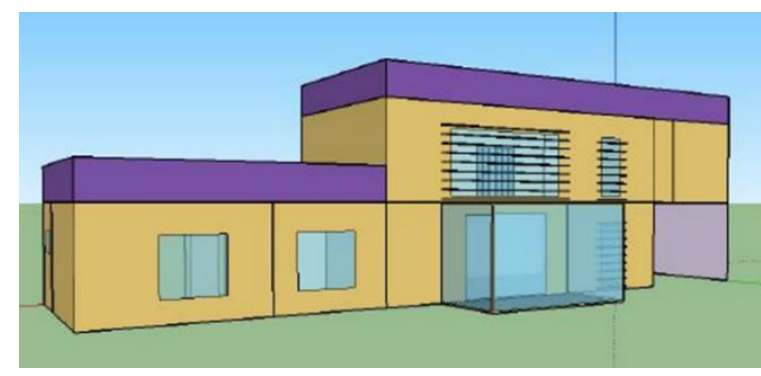

Figure 1. Pelotas Passive House model 
The project study consists of a single-family residence as can be seen the floor plans at Figure 2. The building has a total area of $126.45 \mathrm{~m}^{2}$ divided by two floors and the glazed area corresponds to $24 \%$ of the opaque area of the building. The opening percentage in the northern facade is $24.95 \%, 5.93 \%$ south, $1.97 \%$ east and $5.91 \%$ west (southern hemisphere).

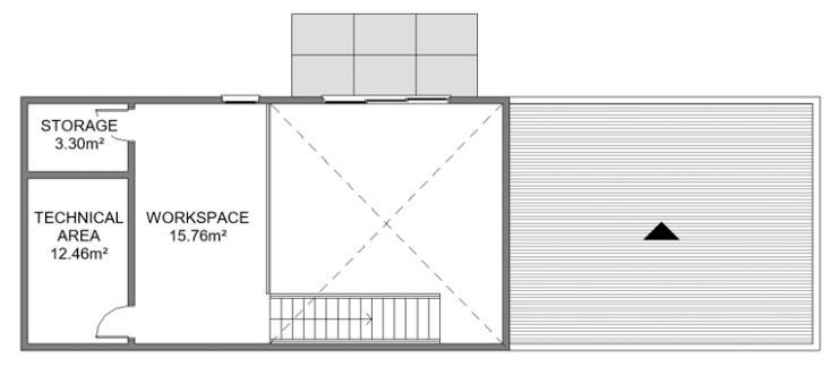

\section{SECOND FLOOR}

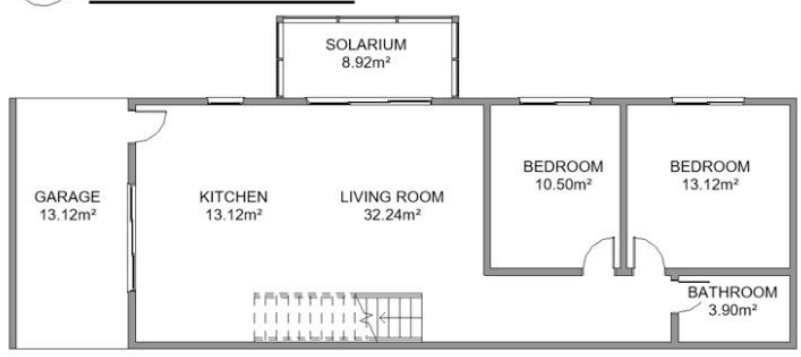

\section{GROUND FLOOR}

Figure 2. Pelotas Passive House floor plans

All windows have external sun protection shading devices. The ground floor has the kitchen and integrated living room, solarium, two bedrooms, bathroom and garage for one car; on the upper floor are the workspace, the technical area, and a small storage. It was oriented on the East-West, with the north facade maximized, aiming the solar radiation gains in winter. For East and West, the smallest facades were established to reduce undesirable gains in the summer [14-16].

Due to the adoption of the Passive House principles for this building, there is a thermal transmittance of $0.31 \mathrm{~W} / \mathrm{m}^{2} \mathrm{~K}$ for the external walls and $0.41 \mathrm{~W} / \mathrm{m}^{2} \mathrm{~K}$ for the roof. For the reduction of thermal bridges, thermal insulation of expanded polystyrene (EPS) with $8 \mathrm{~cm}$ thickness was used in the envelope of the building. Table 3 presents the thickness $(t)$, the thermal conductivity $(\lambda)$, the thermal resistance $(R)$, the internal and external surface resistances $\left(R_{s i}\right.$ and $\left.R_{s e}\right)$, and total thermal transmittance ( $U$-value) of the construction materials according to Brazilian standard NBR 15220 calculation [5]. The adopted PVC (polyvinyl chloride) framed windows consist of double glazing composed of glass pane Planitherm Ultra N 6mm, air layer $14 \mathrm{~mm}$ and glass pane Planilux 6mm, with a solar factor of 0.57 and $U$-value of $1.5 \mathrm{~W} / \mathrm{m}^{2} \mathrm{~K}$ [16].

The mechanical ventilation system adopted for the project is the type ComfoAir 350 of Zehnder, with an efficiency of $84 \%$ heat recovery, certified by PHI $[16,17]$. The house also has an empirical split air conditioner for the simulation and the equipment has a coefficient of performance $(\mathrm{CoP})$ of $3.0 \mathrm{~W} / \mathrm{W}$ [6] so that the internal setpoint temperature of the house was $20^{\circ} \mathrm{C}$ for heating and $26^{\circ} \mathrm{C}$ for cooling [7].

For the configuration of the model, the Brazilian standard values presented in the RTQ-R [6] were used for occupancy, lighting, and equipment. The value of occupancy adopted was two people per bedroom and the sum of all users in the living room. The occupancy pattern was configured separately for weekdays and weekends as shown in Figure 3. The metabolic rate used was $81 \mathrm{~W} /$ person in the bedrooms and $108 \mathrm{~W} /$ person in the living room and kitchen. The lighting load considered was $6 \mathrm{~W} / \mathrm{m}^{2}$ in the living room and $5 \mathrm{~W} / \mathrm{m}^{2}$ in the bedrooms. The lighting pattern was set up separately for weekdays and weekends as shown in Figure 4. The recommended internal equipment load density is $1.5 \mathrm{~W} / \mathrm{m}^{2}$ for the living room in the 24-hour period. In addition, the weather data used was collected on the Laboratory of Energy Efficiency in Buildings website supplied by the Federal University of Santa Catarina [18]. And to consider ground temperatures the ground domain slab from EnergyPlus was used.

Table 3. Thermal properties of the construction materials

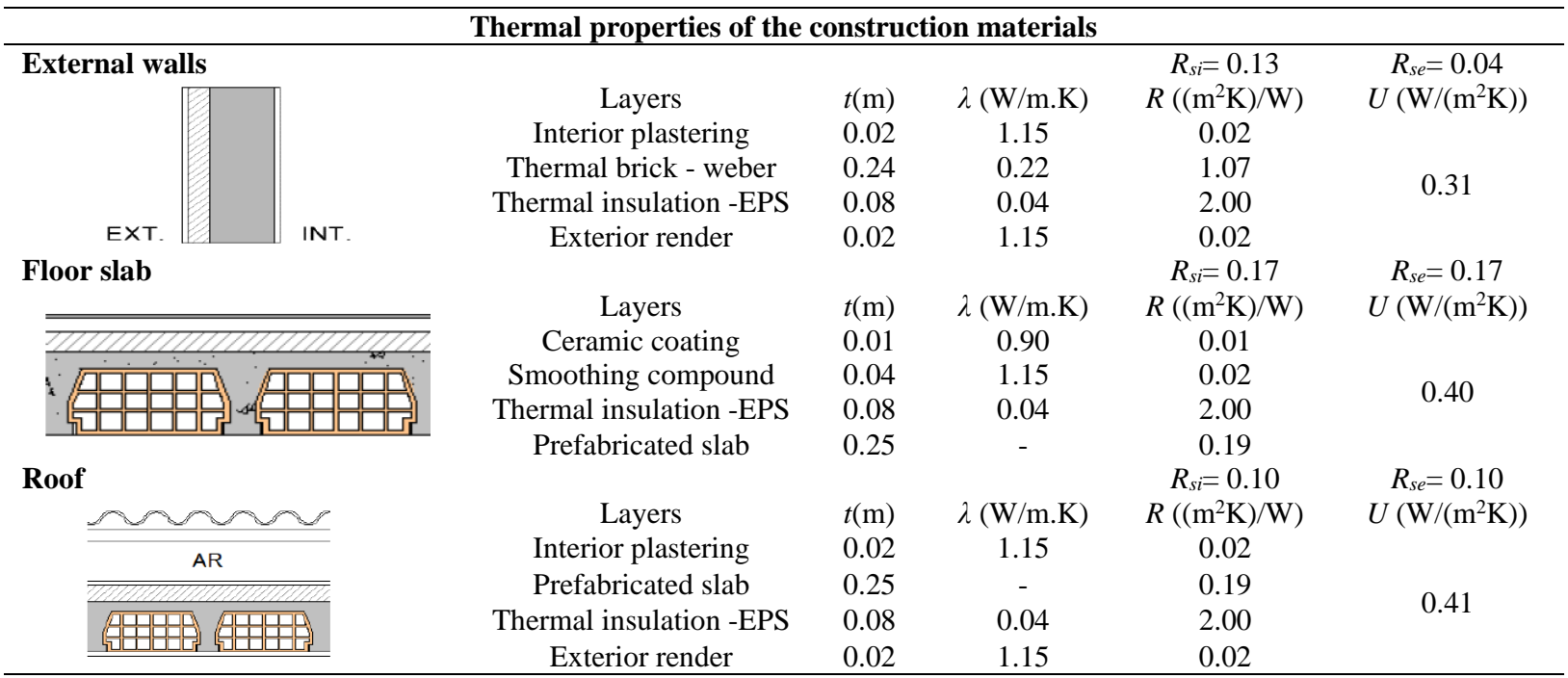

Note: $t=$ thickness; $\lambda=$ thermal conductivity; $R=$ thermal resistance; $U=$ thermal transmittance 


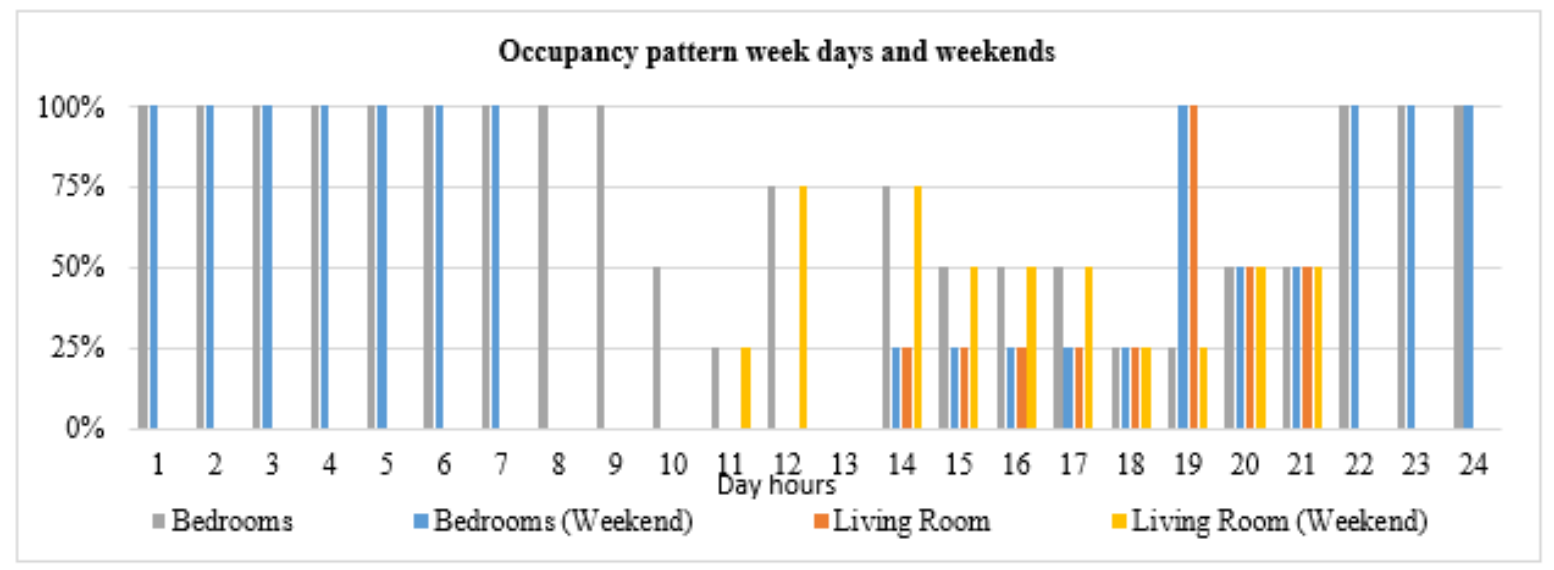

Figure 3. Occupancy pattern for week days and weekends

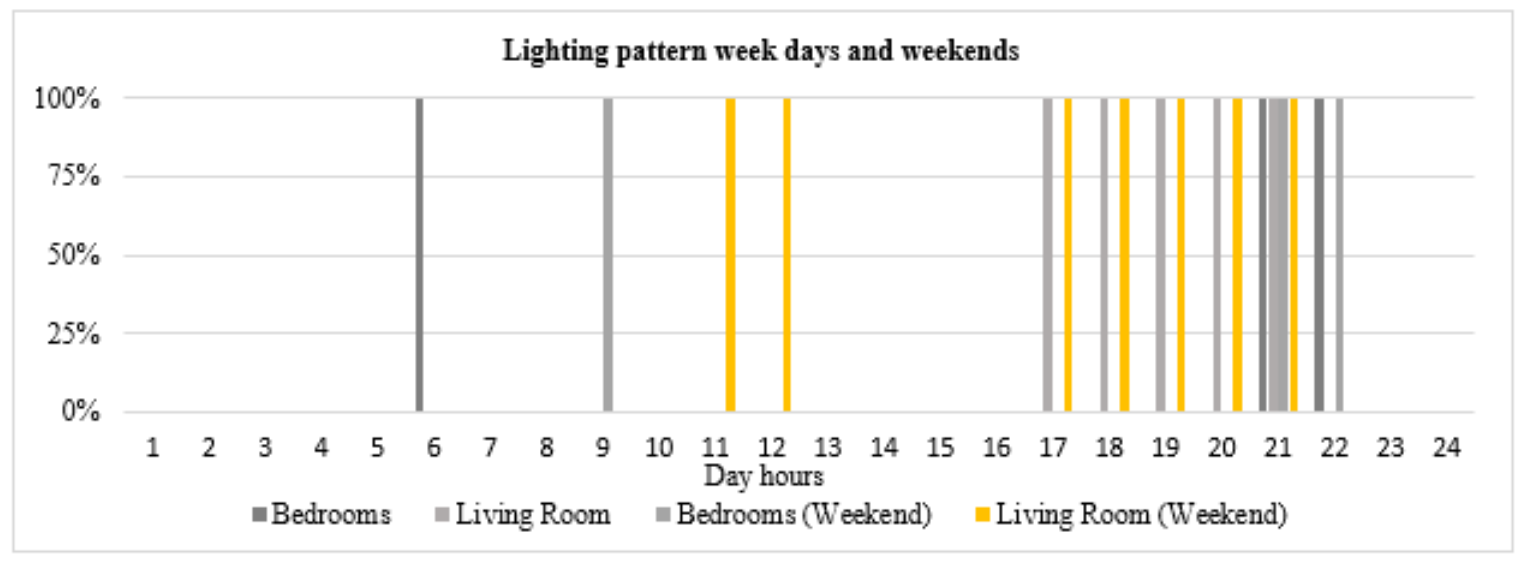

Figure 4. Lighting pattern for week days and weekends

In order to evaluate the applicability of the Passive House standard, the study takes into account the location of the project, the high thermal insulation of the envelope, the thermal transmittance, and absorptance of the envelope (external walls and roof).

The original location of the project is more than $2,000 \mathrm{~km}$ away from the city considered in the study. In Brazil, there are eight Bioclimatic Zones. The Brazilian Bioclimatic Zone represents a homogeneous geographical region regarding the climatic elements that interfere in the relations between the built environment and human comfort. Pelotas is located in Bioclimatic Zone 2 (ZBB2) in which represents $06.4 \%$ of the Brazilian territory and Rio de Janeiro is located in Bioclimatic Zone 8 (ZBB8) in which represents about $53.7 \%$ of the Brazilian territory [6].

Pelotas lies at the coordinate of latitude $31^{\circ} 08^{\prime} \mathrm{S}$, and coordinate of longitude $52^{\circ} 03^{\prime} \mathrm{W}$, and its altitude is $82.5 \mathrm{~m}$, with a humid subtropical climate. In the summer the maximum temperatures vary between $22.9^{\circ} \mathrm{C}$ and $28.2^{\circ} \mathrm{C}$, and shows minimal winter temperatures between $8.6^{\circ} \mathrm{C}$ and $11.2^{\circ} \mathrm{C}$. January which is the hottest month with an average temperature of $23.2^{\circ} \mathrm{C}$ and relative humidity of $77.4 \%$. July, the coldest month of the year, its average temperature is $12.3^{\circ} \mathrm{C}$ and relative humidity is $84.9 \%$ [18].

The Rio de Janeiro is located with coordinates of latitude $22^{\circ} 54^{\prime} \mathrm{S}$, and coordinate of longitude $43^{\circ} 11^{\prime} \mathrm{W}$, and its altitude is $5 \mathrm{~m}$, with a humid tropical climate. In the summer the maximum temperatures vary between $28.7^{\circ} \mathrm{C}$ and $31^{\circ} \mathrm{C}$, and shows minimal winter temperatures between $14.8^{\circ} \mathrm{C}$ and $16^{\circ} \mathrm{C}$. February which is the hottest month with an average temperature of $29^{\circ} \mathrm{C}$ and relative humidity of $66.5 \%$. July, the coldest month of the year, its average temperature is $21.9^{\circ} \mathrm{C}$ and relative humidity is $57 \%$ [18].

For the thermal transmittance of the envelope, three scenarios were considered: the one based on the Passive House standard and the other two values based on the recommendation of NBR 15575 [5]. According to Brazilian standard NBR 15575, for Bioclimatic Zone 8, the recommended thermal transmittance must be less than 3.7 $\mathrm{W} / \mathrm{m}^{2} \mathrm{~K}$ for surfaces with absorptance less than 0.6 and less than $2.5 \mathrm{~W} / \mathrm{m}^{2} \mathrm{~K}$ for surfaces with absorptance greater than 0.6. The absorptance values of the outer surface of the walls and roof correspond to the finish color of these surfaces. The absorptance value 0.35 represents a light color, and the value 0.90 represents a dark color (black, for example). Thus, for the absorptance values, two scenarios were considered: light and dark color, 0.2 and 0.7 respectively.

Table 4 shows a brief summary of all cases under analysis for simulation, with the specifications of the external walls, roofs, and location. Note that the present study seeks to understand if the use of EPS to promote high thermal insulation is advisable in terms of energy savings for the climate context of the project. Considering that high thermal insulation materials are not a popular and typical strategy in the Brazilian construction sector. Therefore, the first two cases (Cases 1 and 2) strictly follow the passive house envelope strategies. In cases 3 to 6, EPS was not used, there is no thermal insulation material on the walls. Consequently, a high thermal transmittance value of the walls is indicated. 
Table 4. Summary of cases under analysis

\begin{tabular}{|c|c|c|c|c|c|}
\hline \multirow{3}{*}{ Cases } & \multirow{3}{*}{ Location } & \multicolumn{4}{|c|}{$\begin{array}{ll}\text { Specifications } \\
\end{array}$} \\
\hline & & \multicolumn{2}{|c|}{ External Walls } & \multicolumn{2}{|l|}{ Roof } \\
\hline & & $U\left[\mathrm{~W} / \mathrm{m}^{2} . \mathrm{K}\right]$ & $\alpha$ & $U\left[\mathrm{~W} / \mathrm{m}^{2} \cdot \mathrm{K}\right]$ & $\alpha$ \\
\hline Case 1 & Pelotas & 0.31 & 0.2 & 0.41 & 0.2 \\
\hline Case 2 & Rio de Janeiro & 0.31 & 0.2 & 0.41 & 0.2 \\
\hline Case 3 & Rio de Janeiro & 2.48 & 0.7 & 1.18 & 0.7 \\
\hline Case 4 & Rio de Janeiro & 2.48 & 0.7 & 1.18 & 0.2 \\
\hline Case 5 & Rio de Janeiro & 1.27 & 0.2 & 1.18 & 0.7 \\
\hline Case 6 & Rio de Janeiro & 1.27 & 0.2 & 1.18 & 0.2 \\
\hline
\end{tabular}

Note: $\alpha$ is absorptance to solar radiation from the external surface of the wall.

Table 5. Thermal properties of construction materials for Cases 3 and Case 4

\begin{tabular}{|c|c|c|c|c|c|c|}
\hline \multicolumn{7}{|c|}{ Thermal properties of the construction materials for Cases 3 and 4} \\
\hline External walls & & & & & $R_{s i}=0.13$ & $R_{s e}=0.04$ \\
\hline \multirow{9}{*}{ Roof } & \multirow{9}{*}{ INT. } & Layers & $t(\mathrm{~m})$ & $\lambda(\mathrm{W} / \mathrm{m} . \mathrm{K})$ & $R\left(\left(\mathrm{~m}^{2} \mathrm{~K}\right) / \mathrm{W}\right)$ & $U\left(\mathrm{~W} /\left(\mathrm{m}^{2} \mathrm{~K}\right)\right)$ \\
\hline & & Interior plastering & 0.025 & 1.15 & 0.02 & \multirow{3}{*}{2.49} \\
\hline & & Thermal brick & 0.2 & 1.05 & 1.07 & \\
\hline & & Exterior plastering & 0.025 & 1.15 & 0.02 & \\
\hline & & & & & $R_{s i}=0.10$ & $R_{s e}=0.10$ \\
\hline & & Layers & $t(\mathrm{~m})$ & $\lambda(\mathrm{W} / \mathrm{m} . \mathrm{K})$ & $R\left(\left(\mathrm{~m}^{2} \mathrm{~K}\right) / \mathrm{W}\right)$ & $U\left(\mathrm{~W} /\left(\mathrm{m}^{2} \mathrm{~K}\right)\right)$ \\
\hline & & Fiber cement tile & 0.007 & 1.15 & 0.01 & \\
\hline & & Aluminum Plate & 0.008 & 230 & 0.19 & 1.18 \\
\hline & & Prefabricated slab & 0.03 & 1.15 & 0.19 & \\
\hline
\end{tabular}

Table 6. Thermal properties of construction materials for Cases 5 and Case 6

\begin{tabular}{|c|c|c|c|c|c|c|}
\hline \multicolumn{7}{|c|}{ Thermal properties of the construction materials for Cases 5 and 6} \\
\hline \multirow[t]{7}{*}{ External walls } & & & & & $R_{s i}=0.13$ & $R_{s e}=0.04$ \\
\hline & & Layers & $t(\mathrm{~m})$ & $\lambda(\mathrm{W} / \mathrm{m} . \mathrm{K})$ & $R\left(\left(\mathrm{~m}^{2} \mathrm{~K}\right) / \mathrm{W}\right)$ & $U\left(\mathrm{~W} /\left(\mathrm{m}^{2} \mathrm{~K}\right)\right)$ \\
\hline & & Interior plastering & 0.025 & 1.15 & 0.02 & \\
\hline & & Thermal brick & 0.2 & 1.05 & 1.07 & \\
\hline & & Interior plastering & 0.025 & 1.15 & 0.02 & 1.27 \\
\hline & & Thermal brick & 0.2 & 1.05 & 1.07 & \\
\hline & INT. & Exterior plastering & 0.025 & 1.15 & 0.02 & \\
\hline
\end{tabular}

In Case 1, there is the original Passive House concept [16], located in Pelotas, Brazil. In Case 2 the only parameter changed was the location, to Rio de Janeiro - Brazil. For Cases 3 and 4, the project location at Rio de Janeiro remains, but the external walls and roof are changed based on Brazilian standard NBR 15575. It is important to highlight that the envelope of Cases 3 and 4 represent the typical wall and roof used components in the Brazilian buildings. The only difference between Cases 3 and 4 is the absorptance value of the roof, which means, the roof color selected in Case 4 is lighter than in Case 3. The composition of the external walls and roof of Cases 3 and 4 are specified in Table 5. Finally, in Cases 5 and 6, there is another external wall option based on Brazilian standard NBR 15575, the double brick wall. The only difference between Cases 5 e 6 is the absorptance value of the roof, in which the roof color selected in Case 5 is darker than in case 6 . The composition of the external walls of Cases 5 and 6 are specified in Table 6 .

\section{RESULTS AND DISCUSSION}

The results from the EnergyPlus software for the six cases under study are specified in Tables 7. The total energy consumption, the total energy consumption per square meters, the total cooling and heating energy demand are presented at Table 7.

In Case 1 due to the lower temperatures in Pelotas, the energy demand for heating is higher when compared to Cases
2 to 6. Considering Cases 1 and 2, in which only the location of the project is changed, there is a significant increase in energy consumption, especially in energy consumption for cooling. This fact occurs due to climatic variation, Rio de Janeiro has a tropical climate and consequently higher temperatures throughout the year, in which results in higher consumption of energy from the air conditioning.

The study is focused on the applicability of the Passive House standard in the city of Rio de Janeiro located in the Brazilian Bioclimatic Zone 8 (ZB8). Hence, the further analysis focuses on energy efficiency between Cases 2, 3, 4, 5 and 6 . According to Table 7, the case with the best energy performance is case 6 , in which the walls and roof have a thermal transmittance equals to $1.27 \mathrm{~W} / \mathrm{m}^{2} \mathrm{~K}$ and $1.18 \mathrm{~W} / \mathrm{m}^{2} \mathrm{~K}$ respectively, combined with an absorptance of 0.2 .

The only difference between Cases 5 and 6 is the absorptance value of the roof, in which a higher value is adopted $(\alpha=0.7)$ for Case 5. An absorptance value of 0.2 ensured significant savings in energy consumption. There is a $20 \%$ reduction in the demand for cooling energy for case 6 . A similar consequence happens between Cases 3 and 4 as well. The only difference between Cases 3 and 4 is the absorptance of the roof, in which a value of 0.2 is adopted for Case 4 . There is a $10 \%$ reduction in cooling energy demand for Case 4 . In Case 3, the dark color of the external walls and roof, work as overheating mechanism, requiring a higher energy demand for cooling when compared to other cases. Therefore, it is possible to conclude that a low value for absorptance, in other words, light color coverage in the project envelope (wall and roof), 
can have a very satisfactory result for energy savings.

Analyzing only the three possible scenarios of thermal transmittance of the walls and the roof, it is possible to conclude that the lower value, which represents the use of high thermal insulation material, does not configure the best proposal in terms of energy savings. The high thermal insulation material (EPS) used on the walls and roof may have caused overheating, preventing heat dissipation. The most efficient scenario belongs to the $U$-value equals $1.27 \mathrm{~W} / \mathrm{m}^{2} \mathrm{~K}$ for walls. This represents the typical double brick wall used in the Brazilian construction sector, the thermal transmittance of the double brick wall is an average value in this study and there is no thermal insulation material on the walls.
Total energy consumption per square meter is the main parameter that the Passive House Institute uses to classify the standard in which a limit value is established. As shown in Table 2 the criteria for Classic, Plus and Premium Standard are respectively: 60,45 and $30 \mathrm{kWh} / \mathrm{m}^{2} \mathrm{y}$. It is concluded, that none of the simulated cases would meet the Premium classification given to consumption below $30 \mathrm{kWh} / \mathrm{m}^{2} \mathrm{y}$. From Case 1 to 6 , there is an annual consumption lower than $45 \mathrm{kWh} / \mathrm{m}^{2}$, however, it does not meet the requirement for renewable energy generation. Since in the project there is no mechanism for such functionality, the Plus classification could not be conferred. Thus, from Cases 1 to 6 , the classic requirements are met and the Classic Passive House standard is conferred.

Table 7. Summary of results Cases 1 to 6

\begin{tabular}{|c|c|c|c|c|c|c|c|c|}
\hline \multirow{3}{*}{ Cases } & \multicolumn{4}{|c|}{ Specifications } & \multirow{3}{*}{$\begin{array}{c}\text { Total Energy } \\
\text { Consumption } \\
{[\mathrm{kWh}]}\end{array}$} & \multirow{3}{*}{$\begin{array}{c}\text { Total Energy } \\
\text { Consumption per } \mathrm{m}^{2} \\
{\left[\mathrm{kWh} / \mathrm{m}^{2}\right]}\end{array}$} & \multirow{3}{*}{$\begin{array}{c}\text { Cooling } \\
\text { [kWh] }\end{array}$} & \multirow{3}{*}{$\begin{array}{l}\text { Heating } \\
{[\mathrm{kWh}]}\end{array}$} \\
\hline & \multicolumn{2}{|c|}{ External Walls } & \multirow{2}{*}{$\begin{array}{r}\text { Roof } \\
U\left[\mathrm{~W} / \mathrm{m}^{2} . \mathrm{K}\right]\end{array}$} & & & & & \\
\hline & $U\left[\mathrm{~W} / \mathrm{m}^{2} . \mathrm{K}\right]$ & $\alpha$ & & $\alpha$ & & & & \\
\hline Case 1 & 0.31 & 0.2 & 0.41 & 0.2 & 4279 & 33.84 & 438.88 & 253.17 \\
\hline Case 2 & 0.31 & 0.2 & 0.41 & 0.2 & 5614 & 44.40 & 2027.90 & 0.00 \\
\hline Case 3 & 2.49 & 0.7 & 1.18 & 0.7 & 5677 & 44.90 & 2064.81 & 25.72 \\
\hline Case 4 & 2.49 & 0.7 & 1.18 & 0.2 & 5094 & 40.29 & 1466.31 & 41.35 \\
\hline Case 5 & 1.27 & 0.2 & 1.18 & 0.7 & 5309 & 41.99 & 1715.87 & 6.73 \\
\hline Case 6 & 1.27 & 0.2 & 1.18 & 0.2 & 4372 & 34.57 & 766.29 & 18.82 \\
\hline
\end{tabular}

\section{CONCLUSION}

The Passive House standard was initially created for cold climates, such as in Central Europe. This study shows that in tropical climates, such as in Rio de Janeiro - Brazil, to meet the Passive House compliance alternative criteria becomes more difficult considering the high thermal insulation material strategy. This approach does not promote high energy saving rates. Thus, it is possible to meet the energy demand requirement for PHI certification for Rio de Janeiro climate, but the thermal insulation strategy is not recommended.

In order to achieve the best energy performance of the building studied, some changes were needed in the Passive House design. Therefore, based on the present pilot case study, it is suggests using less stringent $U$-values for the opaque envelope. The Brazilian standard NBR 15575 provided more efficient results in terms of energy from two popular types of walls used in the Brazilian construction sector in which there is no use of high thermal insulation material.

The building envelope solutions with low $U$-values, e.g. with insulation materials, are very unlike in the Brazilian conventional construction practice and design. The best approach in this study is the medium $U$-values for walls and roof combined with lower absorptance values, which means, light colors.

Lastly, to obtain good results, it is recommended the use of passive design strategies such as the orientation of the building to the east/west axis, suitable building compactness and glazed areas to the north facade. The glazed areas must be protected against solar radiation in the warm periods in order to avoid the overheating.

\section{ACKNOWLEDGMENT}

The authors would like to express their thanks to the CAPES. This study was carried out with the support of the Coordination for the Improvement of Higher Education
Personnel - Brazil (CAPES) - Financing Code 001

\section{REFERENCES}

[1] Empresa de Pesquisa Energética. (2019). Brazilian Energy Balance 2019 Year 2018. Rio de Janeiro: EPE.

[2] IEA. Air conditioning demand set to grow rapidly over the coming decades. https://www.iea.org/newsroomandevents/news/2016/au gust/air-conditioning-demand-set-to-grow-rapidly-overthe-coming-decades.html, accessed on Mar. 17, 2020.

[3] Lamberts, R., Dutra, L., Perreira, F.O.R. (2001). Eficiência Energética na Arquitetura (Energy Efficiency in the Architecture). São Paula: ProLivros. (in Portugese). http://www.labeee.ufsc.br/sites/default/files/apostilas/efi ciencia_energetica_na_arquitetura.pdf., accessed on Aug. $17,2020$.

[4] Associação Brasileira de Normas Técnicas. (2005). NBR 15220: Thermal Performance for Social Interest Housing, Part 2: Calculation Method of Thermaltransmittance, Thermal Capacity, and Thermal Lag of Building Componentes. Rio de Janeiro: ABNT. (in Portuguese). https://www.abntcatalogo.com.br/norma.aspx?ID=635\#., accessed on Aug. 17, 2020.

[5] Associação Brasileira de Normas Técnicas. (2008). NBR 15575: Edifícios Habitacionais de até Cinco Pavimentos (Thermal Performance of Residential Buildings). Rio de Janeiro: ABNT. https://www.abntcatalogo.com.br/curs.aspx?ID=157, accessed on Aug. 17, 2020.

[6] INMETRO (National Institute of Metrology, Standardization and Industrial Quality). (2013). Quality Technical Standards for Energy Efficiency Level in Commercial and Public Services Buildings. Brasília: Eletrobras. (in Portuguese). http://www.pbeedifica. com.br/sites/default/files/projetos/etiquetagem/comercia 1/downloads/Port372-2010_RTQ_Def_Edificacoes- 
C rev01.pdf., accessed on Aug. 17, 2020.

[7] Passive-On Project. (2007). The Standard Passive House-Design Guidelines for Low Consumption Houses. Part I. Review of the Low Consumption Houses. Lisbon. http://www.eerg.it/passive-

on.org/CD/1.\%20Technical\%20Guidelines/Part\%201/P art $\% 201 \% 20-\% 20$ Portugues.pdf., accessed on Aug. 17, 2020.

[8] Wassouf, M. (2014). From de Passive House to the Standard Passive House: The Passive Architecture in Hot Climates. Gustavo Gili, Barcelona, Spain.

[9] Boeri, A., Longo, D. (2011). Energy efficiency in buildings in southern Europe: challenges and design strategies. International Journal of Sustainable Development and Planning, 6(4): 522-536. https://doi.org/10.2495/SDP-V6-N4-522-536

[10] Passive House Institute. Passive House Requirements https://passiv.de/en/02 informations/02 passive-houserequirements/02_passive-house-requirements.htm, accessed on Mar. 10, 2020.

[11] Hacienda, C.D.E.Y., Industria, O.G.D., Minas, E.Y. (2011). Guide of the Standard Passive House - Nearly Zero Energy Consumption Buildings. Fundación de la Energía de la Comunidad de Madrid. https://passivehouse-international.org/upload/Guia-delEstandar-Passivhaus-fenercom-2011.pdf, accessed on Mar. 17, 2020.

[12] Greenan R., Muir B. (2017). New Zealand's building performance pathways. International Journal of Sustainable Development and Planning, 12(2): 252-263. https://doi.org/10.2495/SDP-V12-N2-252-263

[13] McLeod, R., Mead, K., Standen, M. (2016). Passivhaus primer: Designer's Guide. A Guide for the Design Team and Local Authorities. Passive House BRE. https://passivehouseinternational.org/upload/BRE_Passi vhaus Designers_Guide.pdf, accessed on Aug. 2, 2016.

[14] Pouey, J.A. (2011). Residential Project for the
Bioclimatic Zone 2 with Energy Modelling Analysis. Dissertation, PROGRAU-UFPel. Pelotas-RS. https://wp.ufpel.edu.br/prograu/dissertacoes-conforto-esustentabilidade-do-ambiente-construido/3/, accessed on Aug. 17, 2020.

[15] Dalbem, R., Knop, S., Cunha, E., Oliveira, R., Rodrigues, M. Vicente, R. (2016). Verification of the passive house concept to the south of Brazil climate. Journal of Civil Engineering and Architecture, 10: 937-945. https://doi.org/10.17265/1934-7359/2016.08.010

[16] Dalbem, R, da Cunha, E.G., Vicente, R., Figueiredo, A.J., Baptista da Silva, A.C.S. (2017). Discussion of a passive house envelope's performance adaptaded to Bioclimatic Zone 2 according to the RTQ-R. Ambiente Construído, 17(1): 201-222. http://dx.doi.org/10.1590/s167886212017000100132

[17] Passive House Institute. Certificate Passive House Component. Passive House Institute. http://zehnderamerica.com/wpcontent/uploads/2015/05/ ComfoAir-350-HRV-Passive-House-Certificate.pdf, accessed on Mar. 17, 2020.

[18] LABEEE. Arquivos Climáticos. Florianópolis. http://www.labeee.ufsc.br/downloads/arquivosclimaticos, accessed on Mar. 17, 2020.

\section{NOMENCLATURE}

$t \quad$ Thickness, $\mathrm{m}$

$R \quad$ thermal resistance, $\mathrm{m}^{2} . \mathrm{K}^{-\mathrm{W}^{-1}}$

$U \quad$ thermal transmittance coefficient, W. $\mathrm{m}^{-2} \cdot \mathrm{K}^{-1}$

$R_{s i} \quad$ Internal surface resistance, dimensionless

$R_{s e} \quad$ External surface resistance, dimensionless

$\alpha \quad$ Absorptance value, dimensionless

$\lambda$ thermal conductivity, W. $\mathrm{m}^{-1} \cdot \mathrm{K}^{-1}$

$\Psi \quad$ Psi, W. $\mathrm{m}^{-1} \cdot \mathrm{K}^{-1}$ 